\title{
CHRONOLOGICAL DEVELOPMENT OF PUNE FROM 758-2014 AD
}

\section{NITIN N. MUNDHE ${ }^{1} \&$ RAVINDRA G. JAYBHAYE ${ }^{2}$}

${ }^{1}$ Assistant Professor, Department of Geography, Sir Parashurambhau College, Pune, Maharashtra, India

${ }^{2}$ Professor, Department of Geography, Savitribai Phule Pune University, Pune, Maharashtra, India

\section{ABSTRACT}

The aim of the research work is to examine the process of urbanization in Pune, from a small agriculture settlement called "Punnakka" to the cultural capital of Maharashtra. Pune is one of the historical cities of India, with a glorious past, an innovative present and a promising future. Pune has emerged as a prominent location for manufacturing industries, and has now been recognized as the information technology hub and education hub of the country. The city is spread over an area of $250.56 \mathrm{sq} . \mathrm{km}$ with a population of over 3 million. The rapid growth of the city has transformed from its character, as Pensioner's city to Educational - Administrative Center and now to a bustling economic center. The city has experienced a long-standing urban tradition: first as an historical centre of precolonial Urbanism, then as an important military centre during British rule, after independence as a rapidly growing contemporary industrial centre, and today identified as a growing metropolis. This kind of background helps to understand the status, impacts and also to design strategy to promote urban planning in a sustainable manner.

KEYWORDS: Pensioner's city, Pune, Punnakka, Sustainable, Urban Planning, Urbanization \& Urbanism

Received: Sep 17, 2017; Accepted: Oct 03, 2017; Published: Oct 16, 2017; Paper Id.: IJEEFUSOCT20175

\section{INTRODUCTION}

Pune is the second largest and fastest developing city, in the state of Maharashtra and one of the eightmega cities of India [1]. Pune has been well known as the Oxford of the East, Queen of the Deccan, cultural capital of Maharashtra, Pensioner's City, Cycle City and Detroit of India [2]. Pune has a long history and played a significant role in India's pre independence era [3].

According to a local tradition, Pune was a hamlet in 613 A. D. consisting of about fifteen huts [4]. It is quite probable that, Pune at this time was a small village, situated on a raised ground, slightly away from the Mutha River, occupying the southern part of the present Kasba ward. This was the original nucleus, a small village community. The settlement, originally a small hamlet, seems to have grown in size, as a century later we have the first recorded mention of Pune, as the headquarters of Taluka, which was named after it. Pune was referred to as 'Puny Vishaya' in 758 A. D. and 'Punaka Vishava', in 768 A. D., Punya meaning 'holy' and Vishaya meaning 'region'4. It was so described because; the city has a confluence of two rivers Mula and Mutha [5], which is considered holy in the Hindu religion [6]. During the 900s, it was ruled by the Yadava Dynasty, which was defeated by the Mughals in the $11^{\text {th }}$ Century. During the $12^{\text {th }}$ and $13^{\text {th }}$ Century, under the rule of Allaudin Khilji and later Muhammad Tuglaq, several Maratha noblemen served these rulers. Hence, for a long time, Pune was under the Muslim rulers [7].

In 1604, the Sultan of Ahmednagar, granted Pune, then a small village, to Maloji Bhosale grandfather of 
Shivaji. The city was the jahagiri of Chhatrapati Shri. Shivaji Maharaj, till the $16^{\text {th }}$ century and till that period, the city was growing slowly [8]. Chhatrapati Shivaji Maharaj, established a Maratha kingdom in the $17^{\text {th }}$ century. In the $18^{\text {th }}$ century, the Peshwas expanded the Maratha kingdom in Northern India [9]. The Maratha kingdom from 1600 to 1817, after which, the British rule came into force and ruled the city [10]. The city further extended beyond Kasba Peth, up to the river towards the western side, up to Shankarsheth Road, on the Southern side and up to Cantonment on the Eastern side. During British rule, the city gained prominence as an educational, military, and administrative base [11]. The city was divided in 18 Pet, which is termed as the core city. Many religious temples, Churches, Mosques were constructed in the City [8]. The residential development was mostly taking place in the city, with some sporadic commercial development, taking place in Budhwar Peth, Ravivar Peth, Bhawani Peth and Nana Peth [2].

After independence, the city focused its attention on economic growth and development [12]. Due to its glorious past, Pune is known as the "cultural capital of Maharashtra" [13]. After the adoption of an economic liberalization policy in the 1990s, Pune started making big investments in the IT and manufacturing industries and gradually gained its position as an IT and automobile hub [14 15 16]. The city has transformed from its embryonic form of a Kasba peth, to a huge city of 250 sq. km, with immense potential to become one of the top cities of India [17]. The historical background has a vital role in designing sustainable urban planning and management. Understanding the past urban growth will help in better prediction of future urban growth and its impact on all human activities in the future. Therefore, the present research works aim to examine the chronological development of Pune, from 758 to 2014 A. D.

\section{Geographical Location of Pune}

Pune city is located at $18^{\circ} 25^{\prime} \mathrm{N}$ and $18^{\circ} 37^{\prime} \mathrm{N}$ latitude to $73^{\circ} 44^{\prime} \mathrm{E}$ and $73^{\circ} 75^{\prime} \mathrm{E}$ longitudes and at an altitude of $560 \mathrm{~m}$, above mean sea level on the eastern slope of Sahyadri hills in Pune district see in Figure 1. It is the blessed with Mula and Mutha Rivers. Two more rivers, Pavana and Indrayani, flow through the northwestern periphery of the urban area. There are Khadakwasala, Panshet, Warasgaon and Temghar dams, on the upstream of Mutha River, which provides drinking water to the city and irrigation to many villages along downstream [18]. A number of National and State Highways pass through the city. Prominent among them are Mumbai-Banglore NH-4, Pune-Nashik NH-50, PuneSolapur-Hyderabad NH-9 and State highway Pune- Ahmednagar SH-27 etc. [11]. Pune is bounded by the district Thane in north-west, district Raigad in the west, district Satara in south, district Solapur in south-east and district Ahmednagar in north and north-east direction [19].

\section{Demographic Details}

The growth and development of any city are reflected in the change in its population pattern, for example its birth rate, death rate and migration. According to the District Census handbook of Pune, 1971, the population of Pune city in the year of 1891 was around 1.18 lakhs [1]. It remained more or less the same, at around 1.20 lakhs, in the year of 1901. Slower population growth in this decade can be attributed to high death rate, due to severe droughts that the region faced during this time. Even during the period 1901 to 1921, the population size did not a significant increase. This was because; the region had to face several epidemics, including influenza during this period [20]. In the year of 1921, the population size of the city increased to 1.46 lakhs [1].

In the year of 1941, the population size reached 2.57 lakhs. When the Pune Municipal Corporation was set up in 1951, it catered to a total population of 4.85 lakhs. The main reasons for a significant change in the population size from 1920 to 
1950 were increased in employment and business opportunities after the II world war and large-scale migration from Pakistan after the partition and from other neighboring countries [21]. The population in 1961 was 5.95 lakhs, which went up to 12.03 lakhs in 1981. According to the census 2011, the population of Pune city was 31.15 lakhs. There is a growth of more than six times in the city's population in the last 60 years, from 4.85 lakhs in 1951 to 31.15 lakhs in 2011 [1]. The decadal growth rate from 1991 to 2001 was 50.08 \%, more than double the national rate. A large part of this rapid growth has been due to the high level of migration, expansion of educational institutions, particularly in professional courses, expansion of a large number of Government institutions, industrialization of PMC/PCMC after 1960 and expansion of information technology (IT) industry [22]. The trends in population growth of Pune city are summarized in Table 1.

Table 1: Population Trends of Pune City

\begin{tabular}{|c|c|c|c|}
\hline Year & Total Population & Year & Total Population \\
\hline 1851 & 73000 & 1951 & 488419 \\
\hline 1891 & 118790 & 1961 & 606777 \\
\hline 1901 & 153320 & 1971 & 856105 \\
\hline 1911 & 158856 & 1981 & 1203363 \\
\hline 1921 & 198523 & 1991 & 1691430 \\
\hline 1931 & 198078 & 2001 & 2538473 \\
\hline 1941 & 257554 & 2011 & 3115431 \\
\hline
\end{tabular}

Source: 1) District Census Handbook, Census 2001, Pune District pp. 654 to 657. 2) census2011. co. in/census/city/375-pune. html.

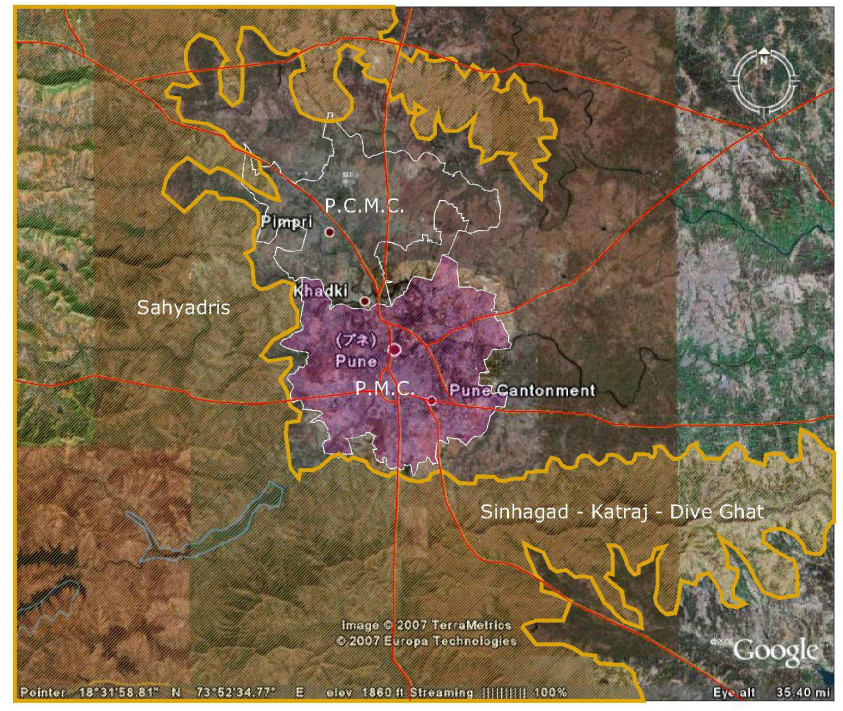

Figure 1: Geographical Setting of Pune City

Source: Generated from Google Earth

\section{OBJECTIVE}

The main objective of the present research works to examine the chronological development of Pune City, from $8^{\text {th }}$ century to $21^{\text {st }}$ century. Pune city has a long history of over a thousand years or more.

\section{Chronological Development of Pune}

Pune served as not only the proud capital of the Peshwas, who headed the formidable Maratha confederacy, but also the acknowledged capital of Maharashtra and the symbolic centre of power for larger parts of India [23]. 
The chronological development of Pune city can be divided into four distinct phases. Each phase has made a special contribution to the development of Pune [8].

- $\quad$ Pre - Maratha Period up to 1600

- $\quad$ Maratha Period (1600-1817)

A. Bhosale Dynasty (1600-1680)

B. Period of Peshwas (1713-1817)

- Development by Bajirao Peshwa (1726-1740)

- Development by Nanasaheb Peshwa (1740-1761)

- Development by Madhavrao Peshwa (1762-1772)

- Development between $1773-1817$

- $\quad$ The British Period (1818-1947)

- Post Independence Period

\section{Pre - Maratha Period up to 1600}

The history of Maharashtra region goes back to the $3^{\text {rd }}$ century B. C, when it was part of the Satavahan Empire [24]. Later, the region came under the influence of powerful dynasties like the Vakataka, Kalchuri, Rashtrakuta, Chalukya, Shilahara and Yadava. The earliest evidence found (copper plates of 758 A. D. and of 768 A. D.) [20] Indicates that, the Rashtrakutas ruled this region then. At that time, Pune was referred to as Punaka Vishaya and Punya Vishaya, here Vishaya means region. Copper plates of 960 A. D and 963 A. D refers to Pune as Punaka Wadi and Punaka Desha [2]. Later on, the city has been mentioned as Kasabe Pune [25].

The term Pune means as Punya-a holy place explains in Pune Gazetteer. In Hindu tradition, a confluence two rivers is sacred. Hence, this city, where there is a confluence of two rivers (Mula \& Mutha), is known as Punyanagari. After the Rashtrakutas, Pune was ruled by the Yadava dynasty [7].

After the Yadava dynasty, Muslim came into dominance till the middle of the $17^{\text {th }}$ century. Initially a Hindu village, a settlement was radically transformed by the coming of Muslims in the late $13^{\text {th }}$ century. The two temples of Puneshwar and Narayaneshwar were converted to Muslim shrines or 'Darghas' of the elder and younger Sheikh Salla respectively [26]. Under Nizamshahi rule, the settlement was fortified and a mud wall was built around the town. The walled portion of the town known as 'Pandharicha Kot' formed a small rectangular space within, which loved the garrison and few Muslim villagers. At the end of the $13^{\text {th }}$ century the first traces of a market town called, 'Kasbe Pune' was developed by an Arab military governor, by combining the villages of Kasarli and Kumbarli to its east [27].

The population within the fort was small as it consisted only of the Muslim army and few villagers. The Hindu cultivators, traders, village-officials and Brahmins lived outside the fortifications. During the Muslim period, the town continued to grow. Three new wards were added to the existing Kasba ward and when in 1595 it was conferred as 'Jagir' on the Maloji Bhosale (grandfather of Shivaji), it consisted of four wards- Kasba, Shaniwar, Raviwar and Somwar [28]. 


\section{Maratha Period (1600-1817)}

\section{Bhosale Dynasty (1600-1680)}

The important decision of Shahaji, was to send his wife Jijabai and their young son Shivaji to live in Pune. They were to look after his 'Jagir', as he had to be away in Karnataka, at the orders of the Bijapur King. The care of the family was entrusted to Dadaji Konddev, a loyal and trusted administrator. The arrival of Shivaji and his mother in Pune, their official residence, the place 'Lal Mahal', led to the increase social life and activity in Pune [8]. The residence with abovementioned temple-complex in its vicinity became the focal point in the urban landscape.

Jijamata founded the Kasba Ganapati temple, the gram daivat of Pune, got built the Lal Mahal the royal palace and hence, she can be considered as the first pioneer of the modern Pune [29]. The location of the Kasba Ganapati temple and the erstwhile expanse of the city indicate that, the main entrance to the city was from the southeast part. Gradually, Shivaji established the Maratha kingdom and crowned as the first Maratha King in 1674 [2]. He established an effective civil and military administration and adopted a policy of religious tolerance to accommodate all religions and sects. Under the administration of Shivaji raje, Shahpura was re-established along with Murtazabad.

There were four wards at this time and the most important was undoubtedly the Kasba, inhabited with the ruling family of Bhosalas and others of considerable importance. During the second half of the $17^{\text {th }}$ century Pune continued to changes its masters between the Moghals, on the one hand and the Marathas on other. On 1663, Shahista Khan, the Mughal viceroy of the Deccan deputed by Aurangzeb attacked Pune. Shivaji defeated him by his guerilla tactics. However, the Muslims again conquered Pune. In 1664, Shivaji shifted his capital to Raigad, as he found Pune too vulnerable to attack [30]. In 1667, Aurangzeb restored Pune to Shivaji. Shivaji was coroneted as king of the Hindu state in 1674 [8]. During this period Mangalwar ward on the eastern bank of Nagzari was added to the four already existing wards [28]. The town, however could not develop much because of the political disturbance.

\section{Period of Peshwas (1713-1817)}

After a Shivaji's death in 1680, the officers of Aurangzeb occupied Pune. Sambhaji, son and successor of Shivaji, died at Tulapur near Pune in 1689 [6]. During the difficult days following the death of Sambhaji the capital of Hindu state was shifted to Satara [2]. When the Mughal Emperor Aurangzeb died in 1707 and his heir released Shahu son of Sambhaji, from captivity at the Mughal court. This was a part of the Mughal political strategy to divide the Maratha movement, and it succeeded for a while. However, Shahu soon gained control and was recognized as Chhatrapati with his capital at Satara. At the time of his release, the Mughals gave the Pune region, which had been his family's 'Jagir', back to him. Thus, Pune city once again came into Maratha hands. Shahu handed Pune, as part of a large Jagir which included the surrounding areas, to his Peshwa (Prime Minister) Balaji Vishwanath Bhatt, (revenue clerk) Chitpavan Brahmin and appointed his friend Ambaji Trimbak Purandare as administrator of Pune [2]. Shivaji successors could not hold his empire together and so their dynasty declined and power passed to the Peshwa. ${ }^{31}$

Pune city was the seat of the Peshwas, the Prime Ministers of the Maratha Kings from 1713 to 1818. Nine Peshwas ruled Pune city during this period. Over 18 Peths were established during the $18^{\text {th }}$ century. A new fortified palace, Shaniwarwada was built in 1732 [32]. Different Peshwas constructed the various mahals or buildings. There are still remains of a fountain with a thousand outlets called Hazari Karanje. The Peshwas expanded the Maratha Empire in the north and central regions, under their Mahadaji Shinde and Malharrao Holkar [8]. 
Development by Thorale Bajirao Peshwa (1720- 1740)

The first Peshwa Balaji Vishvanath was living in Saswad, a village about $15 \mathrm{~km}$ far away from Pune. As Saswad was an inconvenient place to rule. After the death of Balaji Vishvanath, his successor the second Peshwa Thorale Bajirao (1720-40), constructed a palace named Shaniwarwada in 1730-32. The wall around the palace was constructed after some times and the new building called Mahals were built when Peshwas were ruled over Pune. The first redevelopment was done by Thorale Bajirao Peshwa and Chimajiappa from 1720-1740. This represented the first major urbanisation phase of Pune. Pune, which was vulnerable at the time to attack, was given a fortified base in the form of Shaniwar Wada.

During the period of Bajirao, Murtazabad was renamed, redeveloped and repopulated as Shaniwar Peth. The Bajirao was also responsible for re-establishing Malkapur, Shahpura and Shaistapura, and renamed these as Aditwar (Ravivar) Peth, Somwar Peth and Mangalwar Peth, respectively. Both these Peths were established earlier; however, since these were on the other side of the Nagzari Nala, contact with Kasbe Pune was not that good. This changed when Bajirao redeveloped these two areas. As a flow of people started increasing in these areas, a bridge was needed to cross the stream. A bridge was build here on the stream - known as Jakate Pul, and jakat (octroi), was levied on all goods brought into that part of the city, through the bridge [33]. Chavdi (police stations) were established in Somwar Peth, north of Nageshwar Mandir and to the east of the Maruti Mandir. The integration of Somwar and Mangalwar Peth in Pune, where the first serious expansions, was to the east of the Nagzari [27]. It should also be noted that, Bajirao built the Mastani Mahal in his famed mistress, the beauteous and the legendary Mastani, who was having many talents [9]. Thorale Bajirao expanded the Maratha Empire in the north region shows in Figure 2.

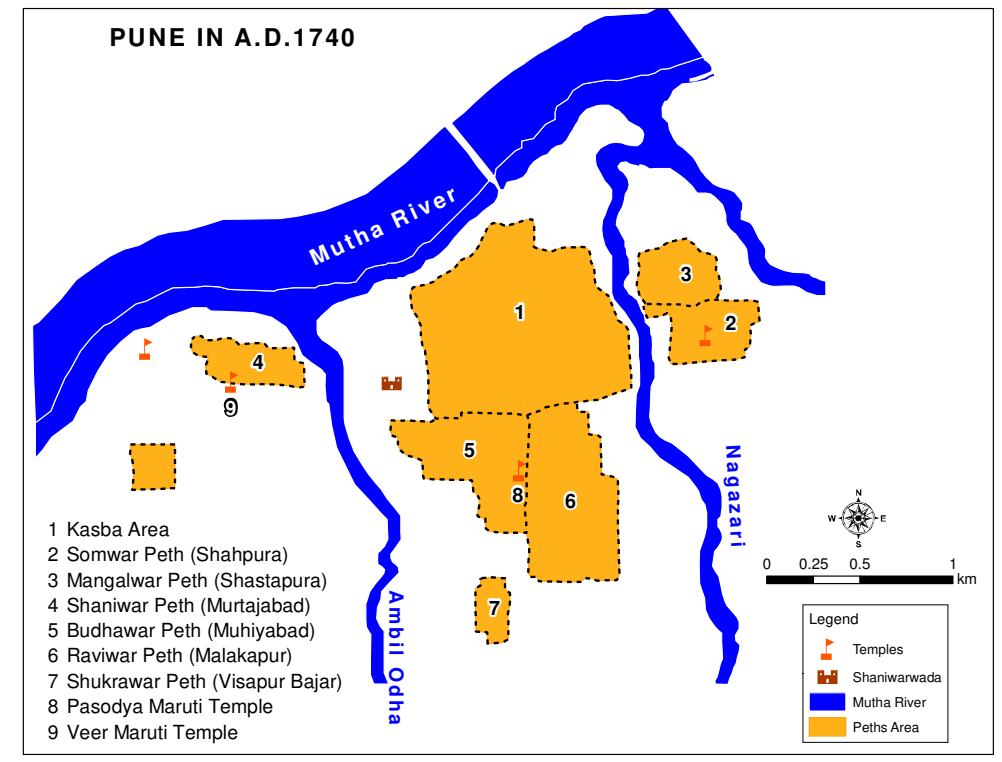

Figure 2: Pune at the Time of Thorale Bajirao Death - 1740

Source: Modified from Datar, 2013

\section{Development by Nanasaheb Peshwa (1740-1761)}

After that, the third Peshwa, Nanasaheb Peshwa (1740 - 1761) hold his position and built the Parvati temple, during his times [34]. He was a brilliant administrator and can be called the person mainly responsible, for giving Pune the structure it has today. In the establishment of wards, Nanasaheb gave the "Koul" to establish Shukrawar Peth in place of 
the earlier Visapur Peth. The northern boundary was marked by initially Akra Maruti and later by Jilbya Maruti, while the southern boundary was marked by Panchamukhi Maruti [23]. The artillery unit of the Peshwa was established in south of Shukrawar Peth. Nanasaheb ordered the installation of Guruwar Peth. Merchants, who specialized in providing fabric of the building filled Gurwar Peth. It includes Gujarati, Marwadi, sonar, Starr, Lodi, tumbles, Mali, bagwan, Mochi, grave, pardeshi etc.

Balaji Bajirao or Nanasaheb had been accountable not just for expanding Pune, but also for its adornment. Many beautiful developments such as the Parvati hill, Hirabag, Sarasbag, Natubag, Belbag and Tulshibag in prosperous area during his time. Old temples falling into decay were renovated and enlarged. Therefore, Visapur set up in the previous reign was the restructuring of the city topography. Vetal and Nagesh-Nihal Peth were found [8].

These development projects were enough to give Nanasaheb a permanent heritage. However, this great administrator also left us a civil engineering amazing thing of the highest order. The glorious project of KatrajShaniwarwada water pipeline to provide drinking water facilities highlight in Figure 3 . The total distance covered by this system was roughly $12 \mathrm{~km}$, and the water thus coming in was distributed to the general population by means of 18 public houds and 40 private houds. This complex water system is a civil engineering wonder, as using only the natural gradient. No motors or any other mechanisms were needed. During the period of Nanasahebs Peshwa, Pune expanded leaps and bounds and its population also increased drastically [9].

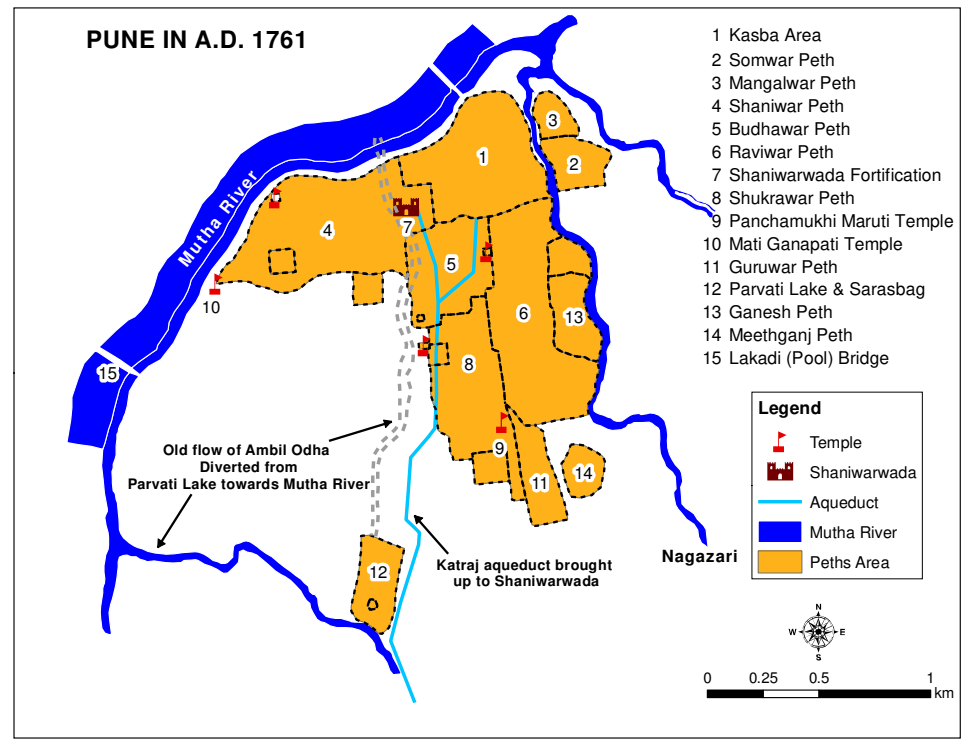

Figure 3: Pune at the Time of Balaji Bajirao Death - 1761

Source: Modified from Datar, 2013

\section{Development by Madhavrao Peshwa (1761-1772)}

After the Nanasaheb Peshwa, Thorale Madhavrao (1761- 1772) hold the position and expand the Maratha Empire by defeated the Nizam and expanding the kingdom. Under the dynamic leadership of the fourth Peshwa, Thorale Madhhavrao, the Marathas made a quick recovery after Panipat. Firstly, he anticipated the importance of expanding east of the Nagzari and thereby gave a Koul to a Mahadaji Vishwanath, a karkoon for the establishment of a new Peth near the Bhavani temple east of Nagzari. The city benefited by the addition of three new peths during the next two decades. These were Bhavani (after a temple of Goddess Bhavani); Sadashiv (after its founder, Sadashiv Rao Bhau, uncle of 
Madhav Rao; it was probably renewed); and Narayan (after the fifth Peshwa Narayan Rao), all set up between 1763 and 1769 [2]. At the same time, he gave a Koul to establish a new peths known as Musafarjang Peth south of Guruwar Peth, which is the area south of Ganj Peth and east of Ghorpade Peth [9].

In 1769, a Koul was given to a certain Appa Mundhe to populate the southwest part of Budhwar Peth. This came to be known as Sadashiv Peth (Figure 4). People of Pune were initially unwilling to settle over here since it was seen to be too far off from the main city. A tax waiver of 7 years was passed for anyone who settled in the area and soon population enlarged. Later, Sadashiv Peth went to be the most prosperous part of Pune city, giving rise to its own unique subculture. The intersection of Sadashiv Peth, Budhwar Peth and Shukrawar Peth were important junction [21]. A new Paar was established with a Maruti Mandir- called as Shani Par. The boundaries of Sadashiv Peth can be traced through the following Maruti temples- Nagnath Paar, Shani Paar [7].

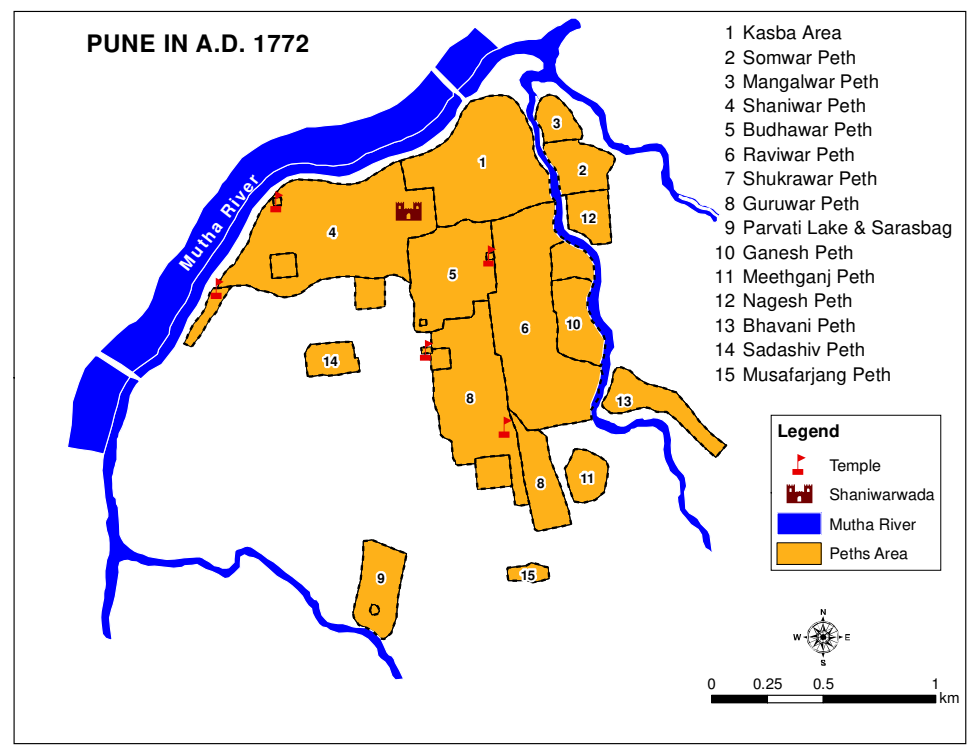

Figure 4: Pune at the Time of Thorale Madhavrao Death - 1772

Source: Modified from Datar, 2013

\section{Development between 1773 - 1817}

In 1773, a Koul was given by Narayanrao to establish the Narayan Peth to relieve the burden on the Sadashiv Peth. Narayan Peth soon flourished and all of Narayan, Sadashiv and Shaniwar Peth were needed to be enlarged to occupy the increasing population.

In the next period of expansion, between 1780 and 1790, four new peths - Rasta, Ghorpade, Nana and Ganj Peths were added, taking the total number of 18 peths. Rasta Peth, developed by Sardar Anandrao Raste as Peth Shivpura, later renamed as Rasta Peth, as well as Ghorpade Peth developed by Sardar Gorpade came up. (Ghorpade Peth is todays Swargate and nearby areas). Nana Peth was named after Nana Phadnis, the most powerful minister in Pune during Sawai Madhav Rao's time (1774-1795). Ganj Peth, as the name implies, was a commercial path, with a large salt store, and predominated by traders, weavers and a large Muslim population of artisans [2].

By 1800, Sawai Madhavrao had died in an accident, and Nana Phadanvis had passed away, and the power and stability of the Maratha Empire were declining. In 1803, Pune and Deccan were struck by one of the worst famines on 
record. Murder, loot, pillage and famine are certainly not conductive to the development of the city. At this time no new words were added. Once the famine was over and peace restored, the last Peshwa was second Bajirao, son of Raghunathrao Peshwa consideration beautifying Pune. Between 1803 and 1813, he built four places like lavish Mahal, Vishrambag Wada and Budhwar Wada etc. [14].

The growth of Pune for some years in the early $19^{\text {th }}$ century was continuous and guided by the Peshwa, but did not last long. There had developed the bitter feeling of opposition between the Marathas and the British, which erupted in 1817 and the Maratha lost to the British in an open battle. Second Bajirao joined hands with British and lastly surrendered to the British and after that, the Peshwa and Maratha dynasty was ending. The rise of the British and the declining glory of the Peshwas in the early $19^{\text {th }}$ century changed the conditions in the town with its 18 wards was still fairly in the prosperous (see Figure 5). Thus escorted in a new phase in the development of Pune, under the leadership of the British [35].

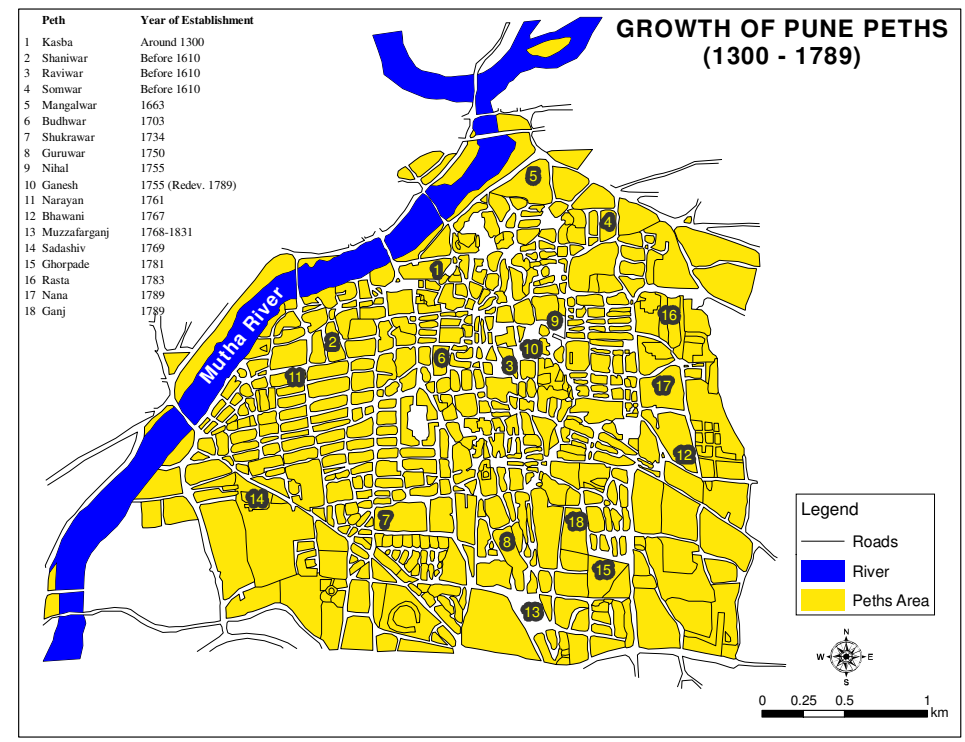

Figure 5: Growth of Pune Peths (1300 - 1789)

Source: Modified from Diddee and Samita, 2000

\section{The British Period (1818 - 1947)}

The Maratha power ended in 1818 and the British set up their empire in Pune city. Under the British, Pune became the 'Monsoon Capital' of the then Bombay Presidency [20]. The British deeply concerned about the security of their rule, and paid more attention to strengthening the cantonments and virtually neglected the town. ${ }^{28}$ The two cantonments Kirkee (Khadki) and Pune guarded the town from two sides [9]. Compared to the city, the cantonments were better planned. As there was plenty of space in the residential section, there was no need for over-crowding and the roads were broad and straight. Large spaces were left open for playgrounds and parade grounds. The standards of cleanliness and comfort set for cantonments were considerably higher than those in the city. Because of excellent climate, affordable living, adequate housing accommodation and excellent educational facilities, large number of civil and military officers began to settle in Pune cantonment after retirement, which attracted more shops of greater variety, independent market, bars and cinema houses and the cantonment in due course became fashionable suburbs of Pune city [24].

Among 1818 - 1900, it was a period of stagnation because British uncared for the city and paid attention to the development of cantonments [35]. The northern part of Sadashiv ward had been planned and laid out in Peshwa time. 
The southern part developed chiefly during the British period. During the British rule, Pune developed rapidly as an educational center and a number of educational societies and institutions sprang up. ${ }^{36}$ Besides, as proper administration was introduced Pune was made the district as well as divisional headquarters.

In 1851 there were in all 10,245 inhabited houses having a population of 73,209 giving an average of seven persons per house [4]. Actually, in the heart of the city, in wards like Shaniwar, Budhwar and Ganesh, the average worked to from 10 to 11 persons per house. The 1851 census reveals that there were in all $21.33 \mathrm{~km}$ of roads [28]. By 1863, this mileage had increased to $28.98 \mathrm{~km}$. By 1882, the city had $51.52 \mathrm{~km}$ of modern metalled roads.

Two major events that shaped the civic growth of the Pune took place in the 1850s. The Pune city Municipality was established in 1857 as an experiment of local self-government and the great Indian Peninsula railway reached Pune (1858). Important developments like the establishment of Sasson hospital 1869, construction of Khadakwasala dam in 1879. The expansion of the civil lines resulted in the formation of a suburban municipality in 1884. A new ward, Shivaji Nagar was created in 1891, to the northwest of the city, enclosing part of the Bhamburda village and this guided in the new development of the city beyond the river as the garden environs [30].

Growth of population in the second half of the $19^{\text {th }}$ century made the establishment of a permanent market a necessity, which was fulfilled, and the present market building was built in 1886. The first market place was in Kasba. Under the Peshwa the market shift from Kasba to Shinwar and came to be held on the large open ground outside the Shaniwar Wada. The market finally shifted from Shaniwar Wada to Shukrawar ward as a well-established center of trade. The occurrence of the market in the Shukrawar ward resulted in more rapid development of the ward.

During the struggle for Indian independence, Pune became an important centre for social and religious reform movements that were sweeping the country, being the residence of social reformers such Mahadev Govind Ranade, Ramakrishna Gopal Bhandarkar, Gopal Krishna Gokale, Maharshi Vitthal Ramaji Shinde and Joytirao Phule. The most important political reformer of this era was Bal Gangadhar Tilak, who dominated the political scene for 60 years during this period. The development across the river was accelerated when a new bridge was built across it in front of Shaniwar Wada in 1924 [20]. The move across the river became official and planned development took place when the villages of Erandwane and Bhamburda (Deccan Gymkhana/ Shivaji Nagar) were incorporated into the city limits in the same year [32]. Important developments that took place in the city up to mid 1900s, were setting up to Aryan Cinema in 1915, underground drainage system for the city in 1919, development of Deccan Gymkhana and other colonies across the river in 1920's, setting up of Silver Jubilee Motor Transport Service in 1941(see Figure 6). The period between 1948 and 1950 saw a great influx of refugees from Pakistan. The Pune Municipal Corporation was established on 15th February 1950 [37]. 


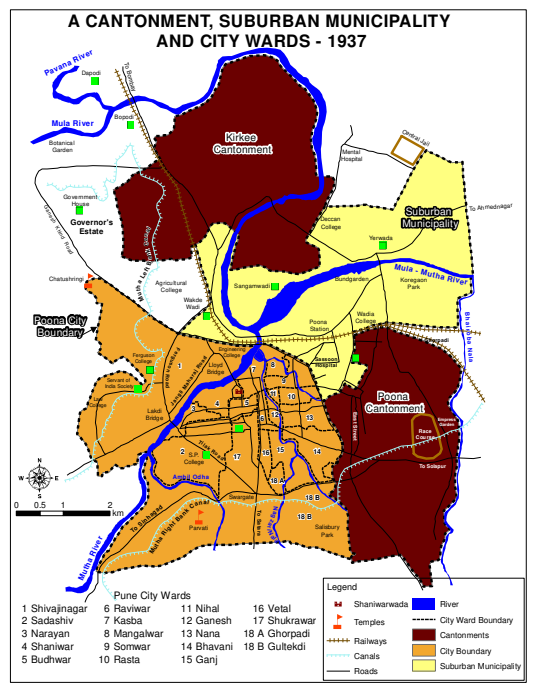

Figure 6: Pune in 1937

Source: Modified from Diddee and Samita, 2000

\section{Post- Independence Period}

After Independence in 1947, one third of Pune's population lived in the dense parts [38]. The riots that broke out after Mahatma Gandhi's death in 1948 affected city development and the homogeneous culture of Pune by bringing nonMarathi refugees to the city. They settled either in the city - near the railway station, in the outskirts of the eastern part of Bhavani and Nana Peths and close to the Sadar Bazaar - or in refugee camps at the then quiet village Pimpri on the Pavana River.

During the British period north-west, area was very important due to the existence of the Government houses, official residence of the Governor in Pune. The old Mumbai-Pune road traverses this area. Establishment of the University of Pune at Ganeshkind in 1949 and the National Chemical Laboratory on the road to Pashan in 1950 considerably accelerated the growth of the city in this direction see in Figure 7. The growth on the southern side of the city was relatively slow, because of the area represented the far end from the Railways [39].

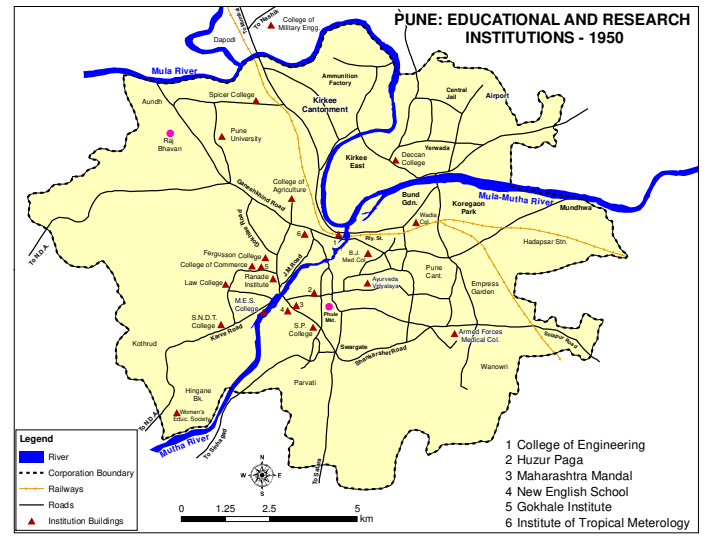

Figure 7: Pune Education and Research Institutions at the Time of 1950

Source: Modified from Diddee and Samita, 2000

The crucial impact on Pune development came from the catastrophic flood of $12^{\text {th }}$ July 1961, the Panshet and Khadakwasla dams broke and their waters flooded the city, destroying most of the older part of the city [9]. As much as 75 
per cent of the houses, bridges and green areas close to the river were washed away by the flood [40]. Many people moved from the flood affected areas to outer wards like Kothrud, Erandavana and Shivajinagar, which were safe, helping in the process the physical growth of the city. In this process, the city government missed both the opportunity to redevelop the historic city center and to plan the fast growing Kothrud into an attractive suburb. Consequently, by 1966, the city had expanded in all directions.

The rapid and extensive industrialization Pune has experienced since the 1960s. The city has transformed from being a "Pensioners Paradise" to the "Detroit of India", with many Indian and international car production plants and other industrial companies in Hadapsar, Viman Nagar, Chakan and Bhosari, The establishment of public-sector Hindustan Antibiotics at Pimpri in 1953 and Kirloskar Oil Engines at Khadki already pointed to the future. Other units began to move in the 1960s - Ruston and Hornsby, Cooper Engineering Works; and other Swedish and German companies, Buckau-Wolf, Sandvik Asia, Atlas Copco, Alfa Laval and KSB Pumps. Telco started operations in 1961, which gave a boost to the automobile sector [41]. The organization of the city - automobile transport services proved a very significant factor in the expansion of the city [24]. The growth, which was hitherto limited to the outskirts of the old town, took deep and isolated suburbs and residential colonies began to develop like Katraj, Kothrud and Shivajinagar etc.

The industrial growth and the subsequent residential growth during post-independence period were largely influenced by the pattern of means of transport like railways and highway, for example Mumbai - Chennai railway line, Pune - Mumbai, Pune - Satara, Pune - Solapur national highways. In 1990, Pune began to attract foreign capital. The maximum growth came after the IT boom and two major IT parks - Hinjewadi and Magarpatta [23]. In 1998, work on the six-lane Mumbai-Pune expressway began; the expressway was completed in 2001. In 2008, the Commonwealth Youth Games took place in Pune, which encouraged additional development in the north-west region of the city. The city gradually changed into a dynamic place of academic, cultural and economic importance. Pune is today acknowledged as an IT hub, educational hub and cultural capital of Maharashtra [42].

\section{The First Urban Growth of Pune}

The growth of the city in the sixties was mainly due to industrial development in the Pimpri - Chinchwad area by private industrialists and MIDC. The bursting of the Panshet dam in 1961 changed the growth pattern and the city started growing along the Mutha River [43]. This development marked the first urban growth, which took place in the earlier sixties after the city bounded across the river and extended to Erandwana in the west, Shivajinagar towards the east, Parvati towards the South and the cantonment in the north direction. Later in the 1970s, the urban growth extended along all the major communication facilities. On the western side, the growth extended up to Kothrud, towards the east to Yerwada and Lohgaon, towards the south Bibwewadi, Hadapsar, Wanwori and towards the north Baner and Aundh [24].

\section{Statutory Development Plans}

Before 1954, there was no statutory plan for Pune city. The local authorities were permitted to undertake the improvement of certain areas in their jurisdiction, by preparing Town Planning Schemes. The first Town Planning Scheme in Pune was prepared for Shivaji Nagar in 1918 [27]. A Master Plan was prepared for the Pune city in 1952 [44]. The first Development Plan according to the new legislation was prepared in 1966. The revision of the Development Plan was undertaken in 1976 and sanctioned in 1987 [45]. As per 1987 DP, the entire planning area within the municipal limits was considered less than six sectors (Table 2 and Figure 8). Eight Town Planning Schemes were finalized till 1989. 
Accordingly, under the notification of Government of Maharashtra in $11^{\text {th }}$ September 1997, 38 fringe villages contiguous to the PMC limits were merged in the Pune Municipal Corporation [44]. In the year 2001, the State Government revised its earlier notification and excluded 15 complete villages and 5 part villages were delinked from the PMC limit. It includes Balewadi, Baner, Bavdhan Khurd, Kothrud, Warje, Hingane Khurd, Wadgaon Budruk, Wadgaon Khurd, Katraj, Dhankawadi, Ambegaon Budruk, Kondhwa Khurd, Kondhwa Budruk, Mohammadwadi, Wadgaon Sheri, Kharadi, Dhanori, Kalas, Shivane (Partly), Dhayari (Partly), Ambegaon Khurd (Partly), Undri (Partly), Hadapsar (partly). The area of these 23 villages is 97.73 sq. $\mathrm{km}$ and total area of PMC limit is now 243.84 sq. $\mathrm{km}$. [46]. The 23 villages assume the shape of a garland around the neck of the old city (Figure 9). The draft Development Plan for the 23 villages was submitted to the State Government on $31^{\text {st }}$ December 2005. The State Government has accorded part sanction to the Development Plan [44]. The state government has taken a decision to merge 28 new villages into the Pune Municipal Corporation's limits. In 2013, the government received a demand for adding 34 villages to the list, for which it sought the opinion of the civic body, emphasize in Figure 10.

Table 2: Sector-Wise Distribution

\begin{tabular}{|c|l|}
\hline Sector & \multicolumn{1}{|c|}{ Area } \\
\hline I & Core area \\
\hline II & Southern suburbs, which consist of Parvati, Dhankawadi, Katraj and Munjeri etc. \\
\hline III & $\begin{array}{l}\text { Southwestern suburbs, which includes Erandawane, Kothrud, Hingne Bk and } \\
\text { Bhamburda etc. }\end{array}$ \\
\hline IV & $\begin{array}{l}\text { Northwestern suburbs, which incorporates Shivajinagar, Aundh, Pashan and } \\
\text { Bopodi etc. }\end{array}$ \\
\hline V & $\begin{array}{l}\text { Northeastern suburbs, which integrates Lohgaon, Yerawada, Wadgaon Sheri, } \\
\text { Kalas, Dhanori and Sangamwadi etc. }\end{array}$ \\
\hline VI & $\begin{array}{l}\text { Eastern suburbs, which includes Hadapsar, Ghorpadi, Mundhwa, Wanawadi and } \\
\text { Kondhava etc. }\end{array}$ \\
\hline
\end{tabular}

Source: Pune Municipal Corporation, 2013

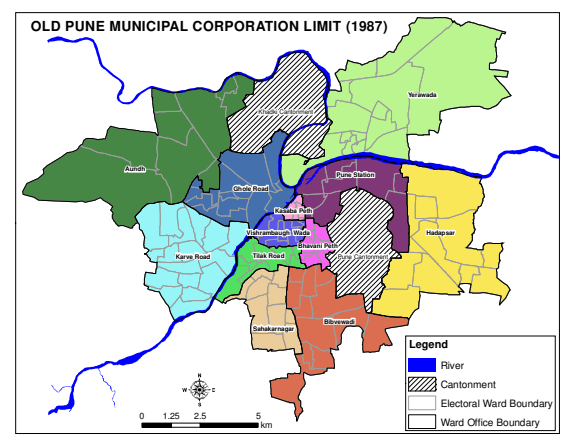

Figure 8: PMC Limit at the Time of 1987

Source: Modified from PMC, 2013 


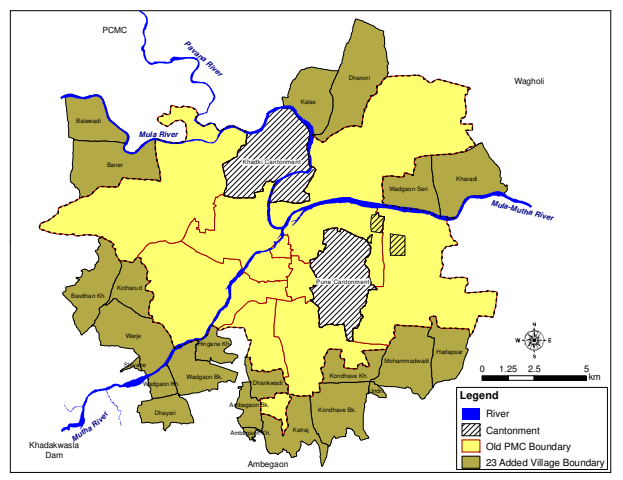

Figure 9: Pune Added 23 Merged Villages in 2001

Source: Modified from PMC, 2013

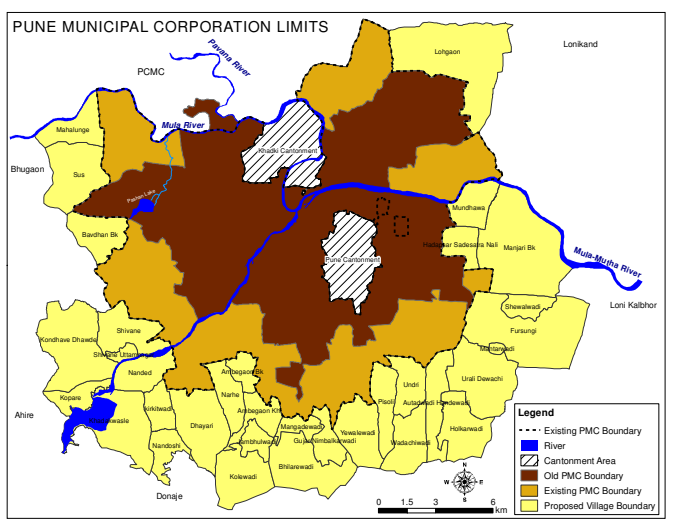

Figure 10: Newly Proposed 34 Villages in Pune

Source: Modified from PMC, 2013

\section{Areal Growth at a Glance}

The precise outline map of Pune was drawn for the first time in 1851 [47]. One does get some idea of the dimensions of the town in the early stages of its growth. At the end of the $13^{\text {th }}$ century, the heart of the city, represented by the fort, where the present Kasba ward. In the $17^{\text {th }}$ century, when it came into the possession of Shivaji it consisted of four wards Kasba, Raviwar, Budhwar and Somwar [9]. It continued to grow during the $18^{\text {th }}$ century and at the fall of Maratha power in 1817; it had 18 wards and covered about 3.22 sq. $\mathrm{km}$ area. In 1857, the total geographical areas of Pune were 7.74 sq. km. In the year 1889-1890, Gultekdi, Erandwane, Erandwane Goathan, Shivajinagar and Shivajinagar Gaothan were added in the city limits, further extending the area to 18.04 sq. Kms [30].

In 1921, the Census office, Government of India, constituted the 'Census Unit' called 'Greater Poona' which marked the boundary of Pune Mahanagar so as to include Pune City Municipality, Pune Suburban municipality, Pune Cantonment, Khadki Cantonment, area of Government House and around eight fringe villages such as Parvati, Ghorpodi, Vanwadi, Bopodi, Yerwada, Aundh, Bhambutda and Erandwane in its vicinity. In 1931, the geographical boundary of the city was further expanded to include the areas of Parvati, Parvati Gaothan, Hingne Budruk and Hingne Gaothan. The city boundary was 18.79 sq. kms. This Census Unit remained unchanged at the two successive decennial censuses. In the period between 1935 and 1950. Chaturshrungi, parts of Ghorpodi and Yerwada, Yerwada Gaothan were included in the city limits [46]. 
In 1958, a total of 18 fringe villages was included in the Pune Mahanagar limits, covering an area of 156.6 sq. km. Out of this Pune city was spread over 129.5 sq. km. This area came under the jurisdiction of Pune Municipal Corporation in the same year. The city was divided into 20 administrative wards with a population of 4.85 lakhs [48]. The decdal growth of geographic expansion during 1941-51 was almost eight fold [21]. In the year 1960 and 1962, the municipal limits were extended twice. The areas added within the extended limits formed four pockets in Dapodi, Katraj, Kondhwa and Lohegaon. During the 1970s. and 1980s. A few more areas got added in the city limit. In 1981, the total geographical area of the city was 145.92 sq. km. It was in the year 1997 that 38 fringe villages were added in the PMC limits, but following the opposition from several villages, 15 complete and 5 partial villages was dropped from the municipal limits in 2001. In 2012, added the Yewalewadi village in PMC limit. In the year 2014, the area under PMC limits was 250.56 sq. km. [49]. However, the state and the Pune Municipal Corporation are convinced about the merger model. To accommodate population and "achieve planned growth" of fringe areas around the city, the state government in 2014 issued a notification to bring 34 fringe villages in the PMC limits, a move which will increase the civic body's geographical area to more than 500 sq. $\mathrm{km}$ from the present 250.56 sq. $\mathrm{km}$. The expanded city could come close to or be even bigger than the Brihanmumbai Municipal Corporation (BMC), which, as the largest civic body in the Maharashtra state. Figure11 shows that Pune city geographic boundary has expanded tremendously from 7.74 sq. km to $250.56 \mathrm{sq}$. km. [49]. An increase in the boundary would mean an increase in the population size.

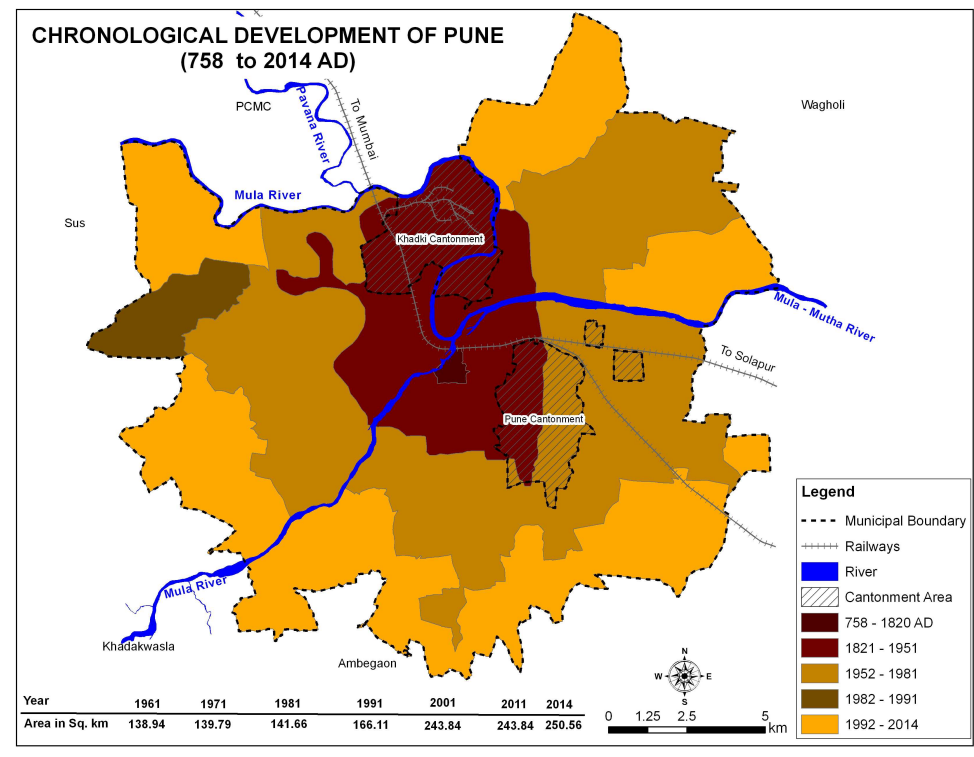

Figure 11: Chronological Development of Pune

Source: Modified from Town Planning Department Pune, 2011

\section{CONCLUSIONS}

The Pune city has also been famous for rich cultural heritage and long history of educational development. It paved strong base for achieving today's recognition 'Oxford of East'. Pune also has a good industrial base since independence, but after IT revolution, it flourished as one of the ideal place in India as well as international as all-major software industries established here. This development attracted human resources from across the country. This review may help in understanding development and issues of urbanization with historical prospective.

Pune city started from a small agricultural settlement called 'Punnakka' in $8^{\text {th }}$ century to prominence under the 
Marathas and the Peshwas until the $18^{\text {th }}$ century. The peak of development was reached during the period of Nanasaheb Peshwa. The decision to build Lakdi Pul opened up the prospects of later developing the areas of Parvati, Erandavane, Deccan and Kothrud. Special credit must be given to Thorale Madhavrav and Nanasaheb Peshwa and their vision as administrators and city planners to give Pune the skeleton and outline at present. The British recognised the importance of Pune and declared the city as the second capital of the previous Bombay Province in the year 1818 A. D and developed Kirkee (Khadki) and Pune cantonment. The headquarters of the southern command situated in Pune is an important army establishment. Under British rule city was developed extensively due to establishment of were schools, colleges, and the army cantonments.

The post independence period has experienced fast growth and expansion of the city due to industrialisation, series of one after another city development plans and development in transport and communication systems. The recent rapid growth of the city triggered by the process of expansion of educational institutions and development of IT industry. It changed its face as a cosmopolitan city.

\section{REFERENCES}

1. Census of India (2011), "Pune District Population Census 2011, Maharashtra literacy sex ratio and density, retrieved August 30, 2015, from http://www.census2011.co.in/ census/district/359-pune.html

2. J. Diddee and S. Gupta, (2000). Pune-Queen of the Deccan, Elephant Design Pvt. Ltd, Pune.

3. Education Landscape of Pune. (n.d.), retrieved from http://www.sse.ac.in/files/EdLandscapePune-TFI_SSEReport.pdf

4. Gazetteer of the Bombay Presidency (1984). Poona, Volume XVIII, part III, 403.

5. Nalawade, S. B., (2007). Geography of Pune Urban Area. Retrieved $4^{\text {th }}$ April 2008.

6. Pune Wikipedia, retrieved from https://en.wikipedia.org/wiki/Pune

7. Gadgil, D. R., (1952). Poona- A Socio-Economic Survey- Part II. Gokhale Institute of Politics and Economics, Pune as cited in Meera Kosambi, 1980.

8. Mahajan, S. G., (2000). Pune City- Its History, Growth and Development (758 to 1998 A.D.). Manasanman Prakashan, Pune.

9. Datar, C. (2013). A Structured and Chronological Study of the Development and Expansion of Pune from A.D 1610 till the Decline of the Peshwa.

10. Geddes, P. (1915). Report on the Replanning of Six Towns in Bombay Residency.

11. PMC, "Comprehensive mobility plan for Pune City", (2008), retrieved from http://www.punecorporation.org/informpdf/CMP/CMP_July_2010/1-iuisl_Pune-CMP-November-2008-chapters-1-6.pdf

12. Van Kampen M. and Van Naerssen, T. (2008). Globalization and urban governance in two Asian cities: Pune (India) and Cebu (The Philippines). European Planning Studies, 16(7), 941-954.

13. Maharashtratourism.gov.in. (n.d.), The Official Website of Maharashtra Tourism Development Corporation Ltd. — Pune, retrieved from http://www.maharashtratourism.gov.in/mtdc/HTML/MaharashtraTourism/Default.aspx?strpage=./Maharashtratourism/Cities toVisits/Pune.html

14. Mangudkar, M. P. (1960). Pune Nagarsanstha Shatabdi Grantha, 23-24. 
15. Palande, P. S. (1981). The Fiscal System and Problems of Municipal Corporations - A Case Study of the Finances of the Pune Municipal Corporation. Unpublished doctoral thesis Submitted to the Pune University, Pune.

16. Kulkarni, A. P. (1991). Employment Multiplier in Pune - Industrial and Employment Growth of an Indian City since 1950. Centre of Studies in Social Sciences, Pune.

17. Ponnuswamy S. and Johnson, D. (2012). Urban Transportation: Planning, Operation and Management. McGraw Hill Education Private Limited.

18. PMC, (2011). Draft Pune city sanitation plan 2011. retrieved from http://www.indiaenvironmentportal.org.in/content/331175/draft-pune-city-sanitation-plan-2011/)

19. PMC (n.d.), “About Pune Municipal Corporation”, Retrieved August 17, 2015, from http://www.punecorporation.org/about_us.aspx

20. PMC, (2008). Socio Economic Survey of Pune City: 2008-2009. retrieved from https://pmc.gov.in/informpdf/City\%20Engineer\%20office/Socio\%20-\%20Economic\%20Survey\%200f\%20Pune\%20City.pdf

21. Wag, D. M. (1993). Pune Ithihas Darshan, Pune Mahanagar (Shakke 1891 to 1872 -Year 1939 to 1951). Bhugol, Vidnyan Tantranyan, Shikshan 1.

22. Mulay, S. (2009). Demographic projections for Pune Municipal Corporation. Retrieved from http://www.punecorporation.org/informpdf/City\%20Engineer\%20office/ Demographic\%20Projection\%20Report.pdf

23. Shekhar, S. (2005). Monitoring Urban Sprawl of Pune by Using Remote Sensing and GIS techniques. Unpublished Ph. D. Thesis Submitted to University of Pune.

24. Malse, V. J. (1990). Urban Sprawl: A Case of Kothrud in Pune City. M.Phill Dissertation Submitted to University of Pune.

25. Kosambi, M. (1989). Glory of Peshwa Pune. Economic and Political Weekly, 24(5), 247.

26. Kantak, M. R. (1991). Urbanization of Pune: How Its Ground Was Prepared. Bulletin of the Deccan College Research Institute, 51, 489-495

27. Gadgil, D. R. (1945). Poona - A Socio-Economic Survey - Part I. Gokhale Institute of Politics and Economics, Pune 12.

28. Sawant,S. B. (1978). The City of Poona, A Study in Urban Geography, Pune University press, Pune.

29. Monuments in Pune, (2008). Pune district administration. Retrieved $4^{\text {th }}$ April 2008.

30. Mahajan, S. G. (2004). Pune Shaharacha Dnyan Kosh, Volume I, Pune Shaharacha Dnyankosh Pratishthan, Pune.

31. Duff, J. G. (1990). History of the Marathas, I, 437.

32. Bhagwat, H. R. (1924). Pune Shaharache Varnan 1901-1920.

33. Kosambi, M. (1980). Bombay and Poona: A Socio Ecological Study of Two Indian Cities, University of Stockholm, Stockholm.

34. PMC, (2013). Environmental Status Report 2013-2014. retrieved from https://pmc.gov.in/en/esr-report-2013-2014

35. Christopher, H. (2000). Queen Victoria: A Personal History. Harper Collins, 221.

36. Chatterjee, A. (2013). Happy to be in Pune. retrieved August 26, 2015, from http://www.telegraphindia.com/1130516/jsp/careergraph/story_16902564.jsp

37. PMC, (2008). Comprehensive mobility plan for Pune City. Retrieved from http://www. punecorporation.org/informpdf/CMP/CMP_July_2010/1-iuisl_Pune-CMP-November-2008-chapters-1-6.pdf 
38. Kantak, M. R. (1991-92). Urbanization Of Pune: How Its Ground Was Prepared. Bulletin of the Deccan College Research Institute, 51/52, 492.

39. PMC (2007). Environmental Status Report 2006-2007.

40. Jedhe, Y. S., Sankhua, R. N. and Dhumal, K. N. (2014). Flood Hazard Mapping for Khadakwasla Waterhsed. International Journal of Innovative Research in Science, Engineering and Technology 3(10), 16720-16727.

41. Rondinelli,D. A. (1983). Dynamics of growth of secondary cities in developing countries. Geographical Review, 42-57.

42. Krishnamurthy, R., Mishra, R. and Desouza, K. C. (2016). City profile: Pune, India. Cities 53, 98-109.

43. Mehta, S. K. (1968). Patterns of Residence in Poona (India) by Income, Education, and Occupation (1937-65). American Journal of Sociology, 496-508.

44. PMC, (2012). Revised City Development Plan for Pune. Retrieved from http://punecorporation.org/informpdf/CDP/Executive_Summary-Revised\%20CDP.pdf).

45. PMC, (2013). Draft development plan for old PMC limit (2007-2027). Published u/s26(1) of M.R and T.P. Act 1966, retrieved August 30, 2015, from http://www. punecorporation.org/dpoldvill.aspx

46. PMC, (2015). Environmental Status Report 2015-2016. Rretrieved from https://pmc.gov.in/en/esr-report-2015-2016)

47. Mundhe N. N. and Jaybhaye, R. G. (2015). Measuring Urban Growth of Pune City Using Shannon Entropy Approach. The Journal of Geography and Geology, 119, 290-302.

48. Director of Census Operations, Maharashtra, (1951). District Census Handbook, Pune District, Part A - Village and Town Directory, Census 1951.

49. Mundhe, N. N. (2016). Monitoring Physical Expansion of Pune City Using GIS and Remote Sensing Techniques. Global Journal for Research Analysis 5(9), 157-158. 